\title{
Origin, Development and Regulation of Human Leydig Cells
}

\author{
K. Svechnikov L. Landreh J. Weisser G. Izzo E. Colón I. Svechnikova \\ O. Söder
}

Department of Women's and Children's Health, Pediatric Endocrinology Unit, Karolinska Institutet and University Hospital, Stockholm, Sweden

\section{Key Words}

Leydig cells • Steroidogenesis • Peritubular cells •

Paracrine development

\begin{abstract}
Sex steroids are crucial regulators of sexual differentiation and the proper development of secondary sex characteristics and patterns of sexual behavior. Since Leydig cells are the primary major producers of these steroid hormones, maintenance of the normal functions of these cells determines the reproductive capacity and fertility of males. The present minireview discusses recent findings concerning endocrine and paracrine regulation of the proliferation, differentiation and involution of human Leydig cells. The physiology and function of the two distinct fetal and adult populations of human Leydig cells are described, with particular focus on the paracrine environment that triggers their differentiation and functional maturation. The roles of established and more recently discovered paracrine regulators of this maturation, including insulin-like factor 3, platelet-derived growth factor- $\alpha$, desert hedgehog, ghrelin and leptin are considered. A brief description of the origin, ontogenesis and functional markers of human fetal and adult Leydig cells is presented.

Copyright $\odot 2010$ S. Karger AG, Basel
\end{abstract}

\section{Introduction}

The development and maturation of Leydig cells are dynamic processes involving interaction between hormones and numerous additional factors. In humans, fetal and adult populations of Leydig cells with distinct lineages have been described. The fetal population represents an essential element of male sex differentiation, as demonstrated by the observation that dysfunction or absence of these cells gives rise to disorders associated with incomplete masculinization of male fetuses $[1,2]$. During the embryonic and fetal period, these cells secrete testosterone and other androgens, which regulate not only the masculinization of internal and external genitalia, but also neuroendocrine functions, thereby influencing behavioral and metabolic patterns.

The development of fetal Leydig cells in humans is a complex process involving cascades of cellular events leading to proliferation, differentiation and involution and associated specific changes in morphology and function. The close functional similarity between fetal Leydig cells and adrenocortical cells found recently suggests a common origin during embryogenesis. Fetal Leydig cells increase in number during the initial 2-3 months following birth and are associated with the increase in plasma

\section{KARGER}

Fax +4161306 1234

E-Mail karger@karger.ch

www.karger.com
(C) 2010 S. Karger AG, Basel

$1663-2818 / 10 / 0732-0093 \$ 26.00 / 0$

Accessible online at:

www.karger.com/hrp
Prof. Olle Söder

Department of Women's and Children's Health, Pediatric Endocrinology Unit

Karolinska Institutet and University Hospital, Q2:08

SE-171 76 Stockholm (Sweden)

Tel. +468517 75124, Fax +468517 75128, E-Mail olle.soder@kbh.ki.se 

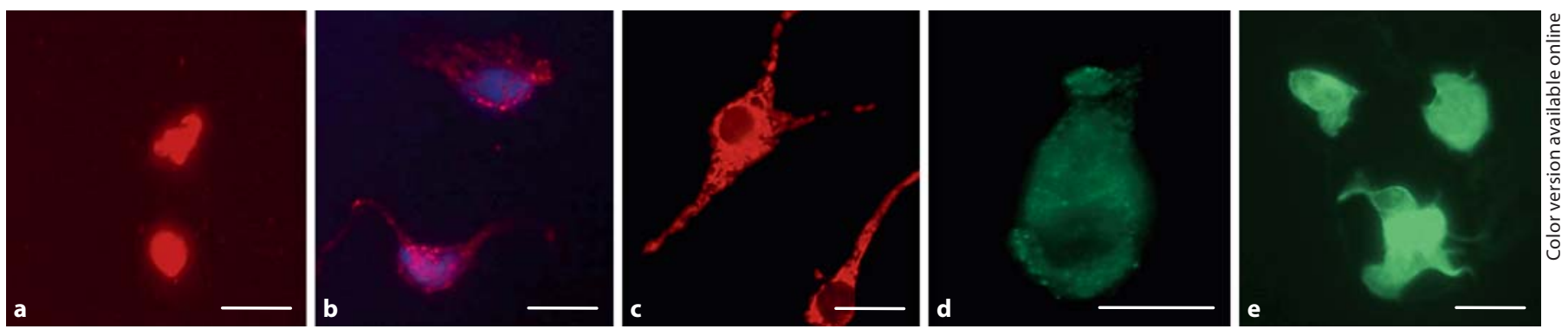

Fig. 1. Immunohistochemical analysis of the expression of receptors and steroidogenic enzymes by Leydig cells and their putative precursors isolated from the rat testis. a Expression of LH receptor by fetal Leydig cells isolated from 7-day-old rats. b Expression of PDGF receptor- $\alpha$ by putative Leydig stem cells isolated from rats 7 days postnatally. c Expression of the steroidogenic acute regulatory (StAR) protein by immature Leydig cells. $\mathbf{d}$ Expression of cytochrome P450scc by adult-type Leydig cells. e Expression of $\alpha$-actin by peritubular cells isolated from 20 -day-old rats. In all cases the cells were subjected to immunofluorescent analysis employing anti-LHR (a), anti-PDGFR- $\alpha$ (b), anti-StAR (c), anti$\mathrm{P} 450 \mathrm{scc}$ (d) or anti- $\alpha$-actin primary antibodies, followed by secondary donkey anti-rabbit IgG conjugated to Cy $3(\mathbf{a}, \mathbf{b}, \mathbf{c})$ or FITC (d, e). Scale bars $=50 \mu \mathrm{m}$. testosterone during this embryonic and early fetal period. These cells possess well-developed steroidogenic machinery expressing both the luteinizing hormone receptor (LHR) (fig. 1a) and the key steroidogenic enzymes (e.g. 3ßHSD, P450scc, P450c17) required for androgen biosynthesis (fig. 1).

The neonatal androgen surge ('baby puberty') [3] may play a role in imprinting various cell types in the prostate, kidney and brain in such a manner they respond appropriately to androgen stimulation during adulthood. Finally, following a prolonged childhood period of steroidogenic quiescence, the Leydig cells are stimulated by the pituitary gonadotropin LH to grow in number and cellular size, and, at the same time, mature and differentiate to initiate the pubertal surge of testosterone required for start and maintenance of full spermatogenesis, development of the accessory sex glands and the appearance of the secondary sexual characteristics. The developmental transitions of the different types of Leydig cells are regulated by a complex cocktail of endocrine and paracrine factors, which trigger cascades of cellular events (e.g. the expression of steroidogenic enzymes and androgen receptor) that optimize cellular activity for each particular period of male development. The present minireview focuses on the current state of our knowledge concerning the biology of the human Leydig cell and, in particular, their differentiation and functional maturation. Particular emphasis is placed on the function of recently discovered regulatory factors in connection with these events.

\section{Developmental Regulation of Fetal Human Leydig Cells}

The development of fetal Leydig cells can be separated into three stages, i.e. differentiation, fetal maturation and involution [4]. In the embryonic and fetal human testis, differentiation occurs at a gestational age of 7-14 weeks; maturation during the weeks $14-18$ of gestation; and the involution thereafter until the time of full-term birth. The maximal number of Leydig cells per pair of human testes $\left(48 \times 10^{6}\right)$ is observed during weeks $13-16$ of gestation [5]. The Leydig cells appear embryonic gonad shortly after testis determination and probably arise from multiple embryonic tissues including the coelomic epithelium, gonadal ridge mesenchyme, and migrating mesonephric cells [6].

Moreover, it has been proposed that fetal Leydig cells may have initially evolved through slight modifications of the fetal adrenal cells [7]. This suggestion is based on the observation that patients suffering from congenital adrenal hyperplasia, which in inadequately controlled cases may be associated with chronically elevated levels of ACTH, develop testicular masses known as adrenal rest tissue [8]. This tissue is generally thought to arise from ectopic adrenal tissue which has failed to separate from the gonad during fetal differentiation [8]. However, it is also possible that in some cases these masses arise from ACTH-sensitive fetal Leydig cells that are probably still present in the testis. Of interest in this context is the observation that chronically elevated secretion of ACTH in a boy with X-linked adrenal hypoplasia due to a mutation in the Dax1 gene was proposed 
to stimulate androgen production and cause precocious puberty [9].

The precursors of fetal human Leydig cells become functionally active as early as after 6-7 weeks of gestation, at which time testosterone can be detected in the human embryonic testis [10]. The differentiation of these cells must be independent of LH, since the onset of testicular androgen production precedes the secretion of $\mathrm{LH}$ by the fetal pituitary [6]. Recently, Lambrot et al. [11] have added more support to this conclusion demonstrating that the capacity of the embryonic testis to produce and secrete testosterone in vitro is greatest prior to 7 weeks of gestation and that this early androgen production occurs without any addition of any exogenous factors or hormones to the culture medium [11]. Furthermore, at this same period in their development, retinoic acid can stimulate the expression of the key steroidogenic enzymes and, thereby, steroidogenesis by human embryonic Leydig cells [11]. These observations provide strong support for the idea that neither hCG secreted by the placenta nor $\mathrm{LH}$ are involved in regulating the initial phase of human Leydig cell differentiation. However, LH does stimulate testicular testosterone production after more than 7 weeks of gestation, indicating that hCG/LH is absolutely required for the maintenance of this production at later stages [12]. This hypothesis receives additional support from the fact that anencephalic human fetuses have a reduced number of Leydig cells and suppressed testicular steroidogenesis suggesting that endogenous gonadotropins control fetal steroidogenesis [12].

Moreover, gonadotropin insufficiency is often associated with undermasculinization including micropenis, which is an indication of insufficient testosterone production by fetal Leydig cells [13]. Similarly, males carrying an inactivating mutation of the LHR exhibit reduced numbers of Leydig cells and show poor development of the external genitalia [14]. However, a certain development of androgen-sensitive organs (e.g. the ductus deferens and epididymis) may occur in these individuals indicating some LH/hCG-independent production of androgen, probably during the initial stages of Leydig cell differentiation. Finally, mutation of the LH $\beta$ gene that eliminates the ability of this hormone to bind to its receptor eliminated Leydig cell development in a patient with male hypogonadism [15].

The Leydig cells proliferate and differentiate gradually and continuously until they attain peak development and maturation before week 19 of gestation, followed by regression [16]. To date, there is no information available concerning the testicular and/or circulating factor(s) that triggers the degeneration of fetal human Leydig cells. Interestingly, in rodents this regression occurs when plasma levels of LH are still high [17], indicating that this gonadotropin is unable to protect the cells from involution. Several signal molecules, including transforming growth factor (TGF)- $\beta$, anti-Müllerian hormone (AMH) and gonadotropin-releasing hormone $(\mathrm{GnRH})$, have been proposed to play a role in the degeneration of fetal Leydig cells in rodents $[18,19]$, however their role in regression of human fetal Leydig cells remains unclear.

\section{Regulatory Factors Controlling the Functions of Fetal Human Leydig Cells \\ Desert Hedgehog}

Although most data concerning the role of Desert hedgehog (Dhh) in the regulation of fetal Leydig cells have been obtained in rodents, there are also reports on the significant role of Dhh signaling in the development normal testicular phenotype in humans [20,21]. In rodents, Dhh is known to be required for the differentiation and expansion of fetal Leydig cells during the embryonic phase. Secreted by the Sertoli cell, Dhh acts in a paracrine fashion to induce the differentiation of both the fetal Leydig cells and of the peritubular myoid cells, surrounding the testicular cords [22]. Mutant mouse male gonads that lack functional Dhh contain no Leydig cells and the consequent absence of androgens results in feminization of the external genitalia of these animals. Recently compound $S f 1+/-$; Dhh-/- mutant male mice were shown not to masculinize and to appear externally female as a result of their lack of differentiated fetal Leydig cells [23]. These findings led to the proposal that the $S f 1$ and Dhh pathways may be necessary for the differentiation and survival of fetal and adult Leydig cells and/or that fetal Leydig cells might be precursors for adult Leydig cells (ALCs) in rodents [23]. Thus, Dhh seems to have a crucial role for the regulation of the embryonic development of fetal Leydig cells in rodents, but a similarly important role of Dhh in humans still remains to be demonstrated.

\section{Platelet-Derived Growth Factors}

Human fetal Leydig cells have been found to express significant levels of platelet-derived growth factor of both isoforms, PDGF-A and PDGF-B, as well as their corresponding receptors, PDGFR $\alpha$ and PDGFR $\beta$ [24]. Therefore, it is reasonable to suggest that the PDGF system is involved in the control of Leydig cell development and function also in humans, similarly to what has been observed in rodents [25]. Deletion of the gene encoding PDGF-A was found to attenuate the expression of cyto- 
chrome P450 side-chain cleavage (P450scc) [25], which converts cholesterol into pregnenolone, and thereby disrupts early Leydig cell differentiation in mice.

\section{GATA- 4 and IGF-I}

The transcription factor GATA-4 may play an important role in controlling human fetal Leydig cell development. The expression of this regulatory molecule in human fetal Leydig cells has recently been shown to peak week 15 postconception, in parallel with the highest testosterone levels of the fetus [26], suggesting a role for GATA-4 in the regulation of steroidogenesis in human fetal Leydig cell. Experiments on rodents have shown that GATA-4 plays a role in the differentiation of and/or steroidogenesis by somatic gonadal cells, including fetal and adult Leydig cells, indicating that this factor may be a key participant in the ontogeny of steroidogenic cells in the fetal testis [27].

Furthermore, some evidence suggests that ligands of the IGF system affect the differentiation and steroidogenic capacity of fetal Leydig cells, both in rodents and humans $[28,29]$. In the human testis, IGFs and the type I IGF receptor are differentially expressed at different maturational stages and seem to be involved in the regulation of Leydig cell proliferation and survival, and steroidogenic maturation [29]. In line with this hypothesis, boys with a genetic deficiency in production of this growth factor are undermasculinized, suggesting a lack of androgen production by their fetal Leydig cells [30]. As stated above GH and IGF-I may also act as survival factors for Leydig cells $[31,32]$. Thus, all of these factors appear to work in concert to trigger the processes that control the differentiation, maturation and regression of human fetal Leydig cells.

\section{Postnatal Differentiation of Human Leydig Cells}

The complex postnatal differentiation of human Leydig cells involves a variety of cellular cascades resulting in mature Leydig cells with the well-developed steroidogenic machinery (fig. 1d) required for testosterone biosynthesis. A triphasic pattern of human Leydig cell development is currently appreciated and accepted as working hypothesis $[33,34]$. Division of the development of human Leydig cells into the three stages is based on the triphasic development of plasma testosterone levels, with the initial testosterone peak appearing at the end of the first trimester of fetal life, when mature fetal Leydig cells are functional [35], the second after 2-3 months of postnatal life [36], and the third peak being established in connection with established puberty and lasting thereafter throughout adulthood, until a decline at old age. Morphometric analysis reflects this fluctuation in testosterone levels, revealing a decline in the number of fetal Leydig cells following their peak development during 14-18 weeks of gestation and the appearance of a new wave of Leydig cells designated as neonatal 2-3 months after birth [34]. The neonatal Leydig cell population during this time-frame is a mix of mature well-developed Leydig cells and smaller cells, which is likely to be fetal Leydig cells undergoing regression [37]. The prominent increase in the numbers of differentiated neonatal Leydig cells does indicate a recruitment of precursors during the neonatal period [5]. However, the origin of the cells responsible for the elevation in blood testosterone levels during the first months immediately following birth has been controversial. Certain authors propose that the fetal Leydig cell population is involved in this phenomenon [5]. This is supported by the observation that cells isolated from the postnatal human testis produce more testosterone and exhibit a more pronounced response to LH during the first 7 months than during the second and third year of life and by the pattern of fetal Leydig cells present [38]. Thus, based on available evidence at the present stage, the neonatal Leydig cell population seems to reach a peak in numbers several months after birth and continue functioning until the first signs of pubertal development appear. During the same time-frame the fetal Leydig cells undergo regression. Subsequently, during the pre-pubertal period the neonatal Leydig cells are gradually reduced in numbers, with some undergoing regression, and others differentiating into immature Leydig cells [34]. In humans, the development and function of neonatal Leydig cells are thought to be controlled by the elevated level of $\mathrm{LH}$, which originates from reactivation of the hypothalamic-pituitary-gonadal (HPG) axis during the neonatal period [39], and is associated with an increased plasma testosterone level [39]. This gonadotropin stimulation of Leydig cell steroidogenesis is a key event in the regulation of the maturation and differentiation of Leydig cells [33]. Thus, blockage of the neonatal activation of the HPG axis by an antagonist of GnRH suppresses the maturation of Leydig cells in primates [41] and abolishes the neonatal rise in testosterone secretion [42].

During puberty or following stimulation with hCG, elongated, immature Leydig cells expressing high levels of steroidogenic enzymes (fig. 1c) can be seen to develop in the outer peritubular layer of the seminiferous tubules of the testis. Similar cells are present in certain pubertal primates, pigs and rodents but are rarely detected in adult 
Fig. 2. A putative scheme for the differentiation of human Leydig cells. Peritubular (PTC) and Sertoli cells (SC) secrete a number of critical factors including LIF, PDGF$\alpha$ and Dhh which trigger Leydig stem cells (LSC) to proliferate and migrate into the interstitial compartment of the testis, where they differentiate into progenitor Leydig cells (PLC). Subsequently, a combination of growth factors and hormones (e.g. LH, $\mathrm{T}_{3}$, IGF-1 and PDGF- $\alpha$ ) activate their signaling pathways that promote transition of the PLC into immature Leydig cells (ILC) and, finally, into the adult Leydig cell (ALC) population.

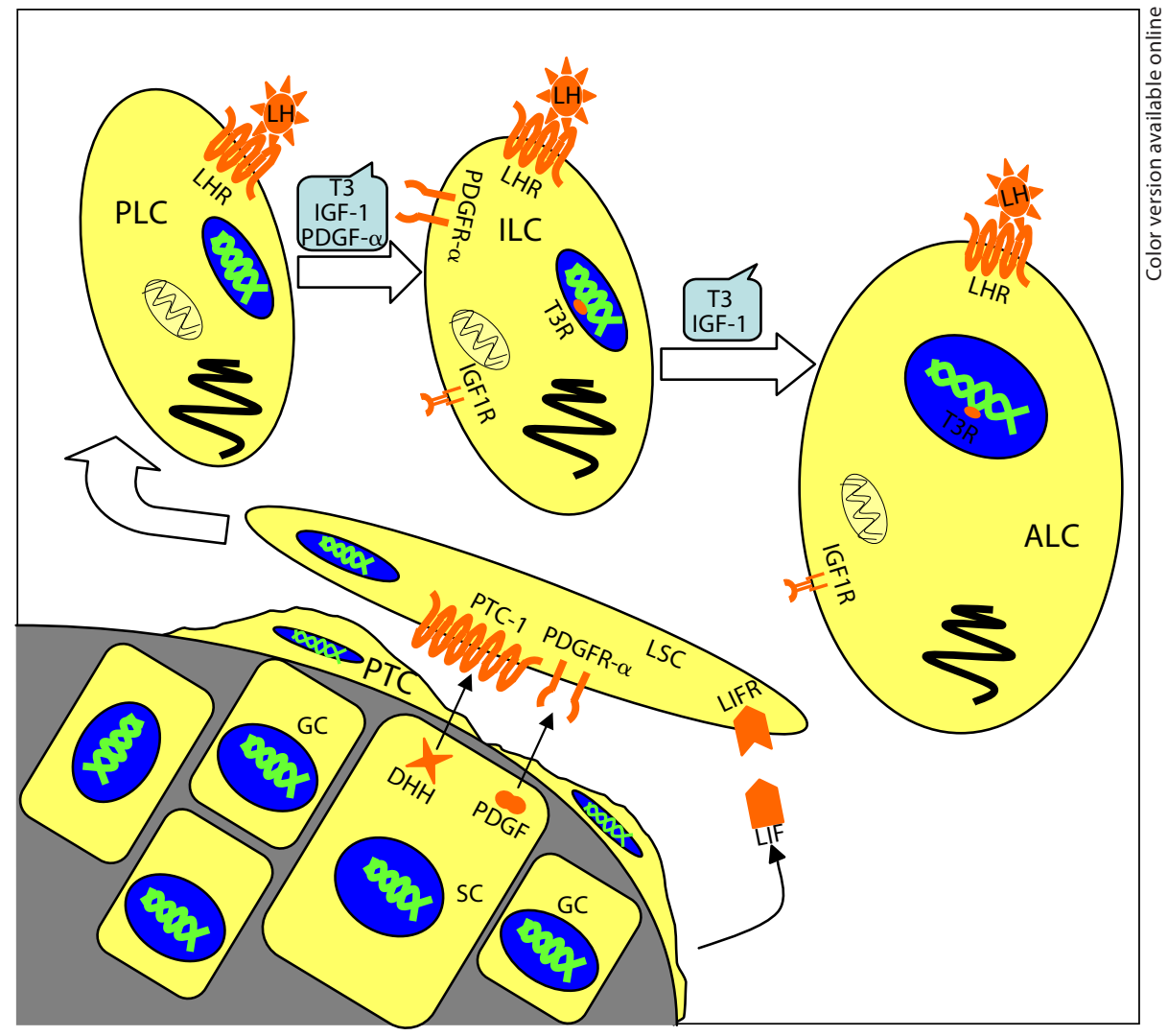

men $[43,44]$. Immature Leydig cells persist throughout childhood and can maturate into adult Leydig cells when puberty is reached.

The enhancement in the numbers of mature Leydig cells that occurs during puberty indicates that precursor cells (e.g. peritubular-like Leydig stem cells and perivascular cells) are being recruited for this purpose [45]. The peritubular-like Leydig stem cells express PDGFR $\alpha$ (fig. 1b) but not the LHR or steroidogenic enzymes [46]. After experimental ablation of Leydig cells with ethane dimethane sulfonate (EDS), peritubular spindle-shaped cells have been shown to be precursors of regenerating Leydig cells in rats $[47,48]$.

These peritubular cells are myoid in nature and express $\alpha$-actin at high levels, which can be used to identify them (fig. 1e). Although these testicular cells are considered to be the immediate source of Leydig cells in postnatal humans, perivascular cells of the interstitial tissue, testicular macrophages and neural crest cells have also been proposed as precursor Leydig cells [47-49]. The latter suggestion is based on several findings that human Leydig cells express a number of proteins typical for neu- ronal and neuroendocrine cells (e.g. neurofilament protein 200 , synaptophysin, neural cell-adhesion molecule) as well as expressing specific markers for glial cell [50, 51]. It has been suggested that following differentiation Leydig cells probably exhibit a phenotype characteristic of cells in the developing nervous system [51]. In addition, a recent study has shown the role for the transcription factor, chicken ovalbumin upstream promoter-transcription factor (COUP-TFII) in controlling differentiation of mesenchymal testicular cells into progenitor Leydig cell lineage in mice [52]. In the absence of COUP-TFII, the maturation of progenitor Leydig cells was disrupted, while this factor was not essential for the maintenance of adult Leydig cell function [52].

The complex postnatal differentiation of human Leydig cells involving a multitude of cellular events (e.g. proliferation and differentiation), is illustrated in figure 2 . During this differentiation, the precursor cells become larger; their abundant cytoplasm becomes eosinophilic, and the cells acquire epithelioid features. All these morphological alterations are accompanied by proliferation and an increasing expression of steroidogenic enzymes 
and the LHR [43], which significantly enhances the capacity for testosterone production. Moreover, the observation that exposure of mesenchymal cells isolated from the prepubertal testes of individuals with androgen insensitivity syndrome to hCG stimulates testosterone production by Leydig cell precursors [45] suggests that $\mathrm{LH}$ has an important role to play in connection with the differentiation and maturation of human Leydig cells. In addition, characterization of male subjects with activating LHR mutations has shown that Leydig cells may play a major role in the production of inhibin B and consequent suppression of FSH levels [53].

Interestingly, certain investigations on both humans and experimental animals have demonstrated that fully mature Leydig cells can dedifferentiate back to their previous stage of development. This event is associated with several morphological changes, including reductions in the volume of the smooth endoplasmic reticulum and number of mitochondria, as well as with impairment of testosterone secretion $[54,55]$.

\section{Regulation of the Function of Human Adult Leydig Cell Lineage}

The influence of various regulatory factors on the cell biology and functions of human Leydig cells have been described in several excellent reviews $[6,16,33]$. Here, the emphasis will be on recently discovered factors that are considered to participate in the regulation of human Leydig cell function.

\section{Insulin-Like Factor 3}

Insulin-like factor 3 (INSL3), a peptide that controls the early phase of testicular descent during embryonic development, is expressed and secreted not only by fetal [56] but also by adult-type human Leydig cells [57]. Importantly, the serum levels of both INSL3 and testosterone in men with Klinefelter's syndrome and consequent infertility due to severe hypospermatogenesis are lowered, suggesting that a reduced circulating concentration of INSL3 might serve as marker for Leydig cell dysfunction [57]. Recently, the INSL3 concentration in the peripheral blood of men has been shown to decline continuously in a linear fashion between the ages of 35 and 80 , a phenomenon that probably reflects a reduction in Leydig cell functionality with age [58]. In line with this assumption, onset of puberty in boys is instead associated with a significant rise in INSL3 levels [59]. Moreover, induction of hypergonadotropic hyperandrogenism in boys with idiopathic short stature by inhibiting CYP19 aromatase with letrazol is accompanied by an enhancement in
INSL3 levels, suggesting that this protein may also serve as an indicator of the onset and progression of puberty [59]. All these reports agree well with recent findings showing that testosterone upregulates the expression of INSL3 in primary rat Leydig cell cultures [60] and stimulates human INSL3 promoter in MA-10 mouse Leydig cell line in vitro via an AR mediated pathway [61], suggesting a positive correlation between testosterone production and INSL3 expression by Leydig cells.

\section{Ghrelin}

The peptide ghrelin, an endogenous ligand for growth hormone, detected in the human stomach, hypothalamus and testis $[62,63]$, is also an important regulator of human Leydig cell function. In the case of the testis, ghrelin has been localized immunohistochemically to Leydig cells and Sertoli cells. At the same time, its receptor, referred to as the growth hormone secretagogue receptor (GHS-R), is present on germ cells, especially pachytene spermatocytes, as well as on Leydig and Sertoli cells [63].

This peptide inhibits both hCG- and cAMP-activated testosterone production by Leydig cells in vitro [64], an effect which is associated with significant attenuation of hCG-stimulated expression of mRNAs coding for several key steroidogenic proteins, e.g. StAR, P450scc, $3 \beta-$ HSD, and $17 \beta$-HSD type III [64]. Regulation of the testicular levels of this peptide in vivo is thought to be dependent on LH, since the virtual obliteration of its expression observed some time after hypophysectomy can be partially restored by treatment with hCG, but not by FSH [65]. The functional significance of ghrelin in the human testis remains to be clarified. Recently, the level of ghrelin expression by Leydig cells was found to be inversely correlated to serum levels of testosterone in patients with normozoospermia, obstructive azoospermia or varicocele, suggesting that this paracrine factor might participate in the regulation of spermatogenesis in humans [66]. This proposal receives further support from the discovery that in seminiferous tubules of the rat testis ghrelin regulates the expression of the stem cell factor (SCF) [63], a major paracrine stimulator of germ cell development which promotes the survival of spermatogonia, spermatocytes, and spermatids in the adult rat seminiferous epithelium [67].

Interestingly, the level of expression of ghrelin by Leydig tumor cells is related to the degree of cell differentiation. Accordingly, highly differentiated Leydig tumor cells exhibit specific immunostaining for ghrelin (albeit with lower intensity than that seen in normal Leydig 
cells), whereas poorly differentiated Leydig tumor cells fail to stain positively for ghrelin. These findings have given rise to the proposal that the level of ghrelin may serve as an indicator of Leydig cell differentiation, both during normal development and in connection with tumorous transformation with loss of ghrelin expression reflecting cellular dedifferentiation [63].

Thus, both INSL3 and ghrelin appear to be reliable indicators of the phase of Leydig cell differentiation and, thereby, of their functional state. In both the rat and humans, mature Leydig cells, which express ghrelin as well as its functional receptor, exhibit no significant proliferative activity [63]. In contrast, proliferating progenitors of rat Leydig cells and poorly differentiated human Leydig tumor cells do not immunostain positively for ghrelin [65].

\section{Leptin}

Leptin, a $16-\mathrm{kDa}$ protein produced primarily by adipose tissue [68] and exerting a significant influence on reproduction and fertility in mammals [69], may be another regulator of human fertility and Leydig cell steroidogenesis. Experiments on rodents have shown that leptin is a potent suppressor of steroidogenesis in Leydig cells. The rapid and dose-dependent inhibition of hCGstimulated testosterone production by primary cultures of rat Leydig cells exerted by leptin is associated with attenuation of androstenedione levels and a concomitant elevation of the levels of the precursor molecules $17-\mathrm{OH}$ progesterone, progesterone and pregnenolone, suggesting that 17-20 lyase is inhibited [70]. Moreover, leptin reduces the expression of mRNAs encoding SF-1, StAR and P450scc, which are key elements of the steroidogenic machinery in this same system [71]. These effects in rodent models are consistent with those observed in humans. Obese individuals demonstrate elevated levels of leptin and reduced concentrations of androgens in their blood [72]. Furthermore, circulating concentrations of leptin have been suggested to be the most reliable predictor of obesity-related attenuation of the androgen response to hCG in vitro [73]. Recently, leptin was demonstrated to be expressed in germ cells, while the expression of the leptin receptor was found exclusively in the Leydig cells of fertile men [74], suggesting that germ cells may exert paracrine control of human Leydig cell steroidogenesis via leptin secretion. In infertile men with obstructive azoospermia, Sertoli cell-only syndrome and varicocele, leptin receptor expression in Leydig cells is inversely correlated with the serum levels of testosterone. Thus, overexpression of the leptin receptor by Leydig cells appears to inhibit testosterone production in infertile men [74], suggesting that signaling transduction pathway(s) downstream of leptin exert negative control over steroidogenesis by human Leydig cells.

\section{Concluding Remarks}

At present, our knowledge concerning the intracellular signaling cascades that control the development of different populations of human Leydig cells is still incomplete. Little is known about the paracrine factors and their signaling pathways that trigger differentiation of these cells in the LH-independent phase of their early fetal development. A variety of paracrine regulators appear to work in concert and the distinct but often overlapping signaling cascades triggered by these molecules require further investigation. The similar characteristics of fetal adrenal and Leydig cells, together with the fact that elevated levels of ACTH can directly stimulate fetal human Leydig cells to produce androgens are of immense potential clinical significance and should be the focus of future research.

In addition, possible reduction of the capacity of fetal human Leydig cells to produce androgens induced by xenobiotics (see, for example $[75,76]$ ), which may lead to incomplete masculinization of male fetuses and various malformations in the reproductive tract, should be explored.

The signaling molecules that trigger the dedifferentiation of fully mature Leydig cells to their previous stage of development are completely unknown and a better understanding of this phenomenon may provide insight into the mechanisms underlying aging and tumorigenesis. Thus, several aspects of human Leydig cell physiology have yet been only poorly explored and further investigation in this area will improve our understanding of the molecular mechanisms through which human reproduction and fertility are regulated.

References

-1 Geissler WM, Davis DL, Wu L, Bradshaw KD, Patel S, Mendonca BB, Elliston KO, Wilson JD, Russell DW, Andersson S: Male pseudohermaphroditism caused by mutations of testicular 17 beta-hydroxysteroid dehydrogenase 3. Nat Genet 1994;7:34-39.

$\checkmark 2$ Caron KM, Soo SC, Wetsel WC, Stocco DM, Clark BJ, Parker KL: Targeted disruption of the mouse gene encoding steroidogenic acute regulatory protein provides insights into congenital lipoid adrenal hyperplasia. Proc Natl Acad Sci USA 1997;94:11540-11545. 
- 3 Forest MG, Sizonenko PC, Cathiard AM, Bertrand J: Hypophyso-gonadal function in humans during the first year of life. 1. Evidence for testicular activity in early infancy. J Clin Invest 1974;53:819-828.

4 Pelliniemi LJ, Niei M: Fine structure of the human foetal testis. I. The interstitial tissue. Z Zellforsch Mikrosk Anat 1969;99:507522.

5 Codesal J, Regadera J, Nistal M, RegaderaSejas J, Paniagua R: Involution of human fetal Leydig cells: an immunohistochemical, ultrastructural and quantitative study. J Anat 1990;172:103-114.

-6 Habert R, Lejeune H, Saez JM: Origin, differentiation and regulation of fetal and adult Leydig cells. Mol Cell Endocrinol 2001;179: 47-74.

7 O’Shaughnessy PJ, Baker PJ, Johnston H: The foetal Leydig cell - differentiation, function and regulation. Int J Androl 2006;29: 90-95; discussion 105-108.

-8 Merke DP, Bornstein SR, Avila NA, Chrousos GP: NIH conference. Future directions in the study and management of congenital adrenal hyperplasia due to 21-hydroxylase deficiency. Ann Intern Med 2002;136:320334.

-9 Domenice S, Latronico AC, Brito VN, Arnhold IJ, Kok F, Mendonca BB: Adrenocorticotropin-dependent precocious puberty of testicular origin in a boy with X-linked adrenal hypoplasia congenita due to a novel mutation in the DAX1 gene. J Clin Endocrinol Metab 2001;86:4068-4071.

10 Tapanainen J, Kellokumpu-Lehtinen P, Pelliniemi L, Huhtaniemi I: Age-related changes in endogenous steroids of human fetal testis during early and midpregnancy. J Clin Endocrinol Metab 1981;52:98-102.

11 Lambrot R, Coffigny H, Pairault C, Donnadieu AC, Frydman R, Habert R, RouillerFabre V: Use of organ culture to study the human fetal testis development: effect of retinoic acid. J Clin Endocrinol Metab 2006;91: 2696-2703.

12 Rabinovici J, Jaffe RB: Development and regulation of growth and differentiated function in human and subhuman primate fetal gonads. Endocr Rev 1990;11:532-557.

13 Sultan C, Paris F, Terouanne B, Balaguer P, Georget V, Poujol N, Jeandel C, Lumbroso S, Nicolas JC: Disorders linked to insufficient androgen action in male children. Hum Reprod Update 2001;7:314-322.

14 Kremer H, Kraaij R, Toledo SP, et al: Male pseudohermaphroditism due to a homozygous missense mutation of the luteinizing hormone receptor gene. Nat Genet 1995;9: 160-164.

15 Weiss J, Axelrod L, Whitcomb RW, Harris PE, Crowley WF, Jameson JL: Hypogonadism caused by a single amino acid substitution in the beta subunit of luteinizing hormone. N Engl J Med 1992;326:179-183.

16 Haider SG: Cell biology of Leydig cells in the testis. Int Rev Cytol 2004;233:181-241.
17 Habert R, Picon R: Control of testicular steroidogenesis in foetal rat: effect of decapitation on testosterone and plasma luteinizing hormone-like activity. Acta Endocrinol (Copenh) 1982;99:466-473.

18 Gautier C, Levacher C, Saez JM, Habert R: Expression and regulation of transforming growth factor betal mRNA and protein in rat fetal testis in vitro. Biochem Biophys Res Commun 1997;236:135-139.

19 Rouiller-Fabre V, Carmona S, Merhi RA, Cate R, Habert R, Vigier B: Effect of antiMullerian hormone on Sertoli and Leydig cell functions in fetal and immature rats. Endocrinology 1998;139:1213-1220.

20 Canto P, Vilchis F, Soderlund D, Reyes E, Mendez JP: A heterozygous mutation in the desert hedgehog gene in patients with mixed gonadal dysgenesis. Mol Hum Reprod 2005; 11:833-836.

21 Fowler PA, Cassie S, Rhind SM, Brewer MJ, Collinson JM, Lea RG, Baker PJ, Bhattacharya S, O’Shaughnessy PJ: Maternal smoking during pregnancy specifically reduces human fetal desert hedgehog gene expression during testis development. J Clin Endocrinol Metab 2008;93:619-626.

22 Yao HH, Whoriskey W, Capel B: Desert Hedgehog/Patched 1 signaling specifies fetal Leydig cell fate in testis organogenesis. Genes Dev 2002;16:1433-1440.

23 Park SY, Tong M, Jameson JL: Distinct roles for steroidogenic factor 1 and desert hedgehog pathways in fetal and adult Leydig cell development. Endocrinology 2007; 148: 3704-3710.

24 Basciani S, Mariani S, Arizzi M, Ulisse S, Rucci N, Jannini EA, Della Rocca C, Manicone A, Carani C, Spera G, Gnessi L: Expression of platelet-derived growth factor-A (PDGF-A), PDGF-B, and PDGF receptor-alpha and -beta during human testicular development and disease. J Clin Endocrinol Metab 2002;87:2310-2309.

-25 Gnessi L, Basciani S, Mariani S, Arizzi M, Spera G, Wang C, Bondjers C, Karlsson L, Betsholtz C: Leydig cell loss and spermatogenic arrest in platelet-derived growth factor (PDGF)-A-deficient mice. J Cell Biol 2000; 149:1019-1026.

26 Ketola I, Pentikainen V, Vaskivuo T, Ilvesmaki V, Herva R, Dunkel L, Tapanainen JS, Toppari J, Heikinheimo M: Expression of transcription factor GATA-4 during human testicular development and disease. J Clin Endocrinol Metab 2000;85:3925-3931.

27 Bielinska M, Seehra A, Toppari J, Heikinheimo M, Wilson DB: GATA-4 is required for sex steroidogenic cell development in the fetal mouse. Dev Dyn 2007;236:203-213.

28 Rouiller-Fabre V, Lecref L, Gautier C, Saez JM, Habert R: Expression and effect of insulin-like growth factor I on rat fetal Leydig cell function and differentiation. Endocrinology 1998;139:2926-2934.
29 Berensztein EB, Baquedano MS, Pepe CM, Costanzo M, Saraco NI, Ponzio R, Rivarola MA, Belgorosky A: Role of IGFs and insulin in the human testis during postnatal activation: differentiation of steroidogenic cells. Pediatr Res 2008;63:662-666

30 Laron Z: Laron-type dwarfism (hereditary somatomedin deficiency): a review. Ergeb Inn Med Kinderheilkd 1984;51:117-150.

31 Colon E, Svechnikov KV, Carlsson-Skwirut C, Bang P, Soder O: Stimulation of steroidogenesis in immature rat Leydig cells evoked by interleukin-1alpha is potentiated by growth hormone and insulin-like growth factors. Endocrinology 2005;146:221-230.

32 Colon E, Zaman F, Axelson M, Larsson O, Carlsson-Skwirut C, Svechnikov KV, Soder $\mathrm{O}$ : Insulin-like growth factor-I is an important antiapoptotic factor for rat leydig cells during postnatal development. Endocrinology 2007;148:128-139.

33 Saez JM: Leydig cells: endocrine, paracrine, and autocrine regulation. Endocr Rev 1994; 15:574-626.

34 Prince FP: The triphasic nature of Leydig cell development in humans, and comments on nomenclature. J Endocrinol 2001;168:213216.

35 Reyes FI, Boroditsky RS, Winter JS, Faiman C: Studies on human sexual development. II. Fetal and maternal serum gonadotropin and sex steroid concentrations. J Clin Endocrinol Metab 1974;38:612-617.

-36 Forest MG, Cathiard AM, Bertrand JA: Evidence of testicular activity in early infancy. J Clin Endocrinol Metab 1973;37:148-151.

37 Prince FP: Ultrastructure of immature Leydig cells in the human prepubertal testis. Anat Rec 1984;209:165-176.

38 Berensztein E, Belgorosky A, de Davila MR, Rivarola MA: Basal testosterone secretion and response to human luteinizing, folliclestimulating, and growth hormones in culture of cells isolated from testes of infants and children. Pediatr Res 1995;38:592-597.

39 Mann DR, Fraser HM: The neonatal period: a critical interval in male primate development. J Endocrinol 1996;149:191-197.

40 Winter JS, Hughes IA, Reyes FI, Faiman C: Pituitary-gonadal relations in infancy. 2. Patterns of serum gonadal steroid concentrations in man from birth to two years of age. J Clin Endocrinol Metab 1976;42:679686.

41 Prince FP, Mann DR, Fraser HM: Blockade of the hypothalamic-pituitary-testicular axis with a GnRH antagonist in the neonatal marmoset monkey: changes in Leydig cell ultrastructure. Tissue Cell 1998;30:651661.

42 Lunn SF, Recio R, Morris K, Fraser HM: Blockade of the neonatal rise in testosterone by a gonadotrophin-releasing hormone antagonist: effects on timing of puberty and sexual behaviour in the male marmoset monkey. J Endocrinol 1994;141:439-447. 
43 Chemes HE, Gottlieb SE, Pasqualini T, Domenichini E, Rivarola MA, Bergada C: Response to acute hCG stimulation and steroidogenic potential of Leydig cell fibroblastic precursors in humans. J Androl 1985;6: 102-112.

44 Rey RA, Nagle CA, Chemes H: Morphometric study of the testicular interstitial tissue of the monkey Cebus apella during postnatal development. Tissue Cell 1996;28:31-42.

45 Chemes H, Cigorraga S, Bergada C, Schteingart $\mathrm{H}$, Rey R, Pellizzari E: Isolation of human Leydig cell mesenchymal precursors from patients with the androgen insensitivity syndrome: testosterone production and response to human chorionic gonadotropin stimulation in culture. Biol Reprod 1992;46: 793-801.

-46 Ge RS, Dong Q, Sottas CM, Papadopoulos V, Zirkin BR, Hardy MP: In search of rat stem Leydig cells: identification, isolation, and lineage-specific development. Proc Natl Acad Sci USA 2006;103:2719-2724.

47 Teerds KJ, De Rooij DG, Rommerts FF, Wensing CJ: The regulation of the proliferation and differentiation of rat Leydig cell precursor cells after EDS administration or daily HCG treatment. J Androl 1988;9:343351.

-48 Davidoff MS, Middendorff R, Enikolopov G, Riethmacher D, Holstein AF, Muller D: Progenitor cells of the testosterone-producing Leydig cells revealed. J Cell Biol 2004;167: 935-944.

49 Jackson AE, O'Leary PC, Ayers MM, de Kretser DM: The effects of ethylene dimethane sulphonate (EDS) on rat Leydig cells: evidence to support a connective tissue origin of Leydig cells. Biol Reprod 1986;35:425437.

-50 Davidoff MS, Schulze W, Middendorff R, Holstein AF: The Leydig cell of the human testis - a new member of the diffuse neuroendocrine system. Cell Tissue Res 1993;271: 429-439.

- 51 Davidoff MS, Middendorff R, Kofuncu E, Muller D, Jezek D, Holstein AF: Leydig cells of the human testis possess astrocyte and oligodendrocyte marker molecules. Acta Histochem 2002;104:39-49.

52 Qin J, Tsai MJ, Tsai SY: Essential roles of COUP-TFII in Leydig cell differentiation and male fertility. PLoS One 2008;3:e3285.

53 Soriano-Guillen L, Mitchell V, Carel JC, Barbet P, Roger M, Lahlou N: Activating mutations in the luteinizing hormone receptor gene: a human model of non-follicle-stimulating hormone-dependent inhibin production and germ cell maturation. J Clin Endocrinol Metab 2006;91:3041-3047.
54 De La Balze FA, Mancini RE, Bur GE, Irazu J: Morphologic and histochemical changes produced by estrogens on adult human testes. Fertil Steril 1954;5:421-436.

55 Dym M, Raj HG: Response of adult rat Sertoli cells and Leydig cells to depletion of luteinizing hormone and testosterone. Biol Reprod 1977;17:676-696.

56 Ivell R, Balvers M, Domagalski R, Ungefroren $\mathrm{H}$, Hunt N, Schulze W: Relaxin-like factor: a highly specific and constitutive new marker for Leydig cells in the human testis. Mol Hum Reprod 1997;3:459-466.

57 Foresta C, Bettella A, Vinanzi C, Dabrilli P, Meriggiola MC, Garolla A, Ferlin A: A novel circulating hormone of testis origin in humans. J Clin Endocrinol Metab 2004;89: 5952-5958.

58 Anand-Ivell R, Wohlgemuth J, Haren MT, Hope PJ, Hatzinikolas G, Wittert G, Ivell R: Peripheral INSL3 concentrations decline with age in a large population of Australian men. Int J Androl 2006;29:618-626.

59 Wikstrom AM, Bay K, Hero M, Andersson AM, Dunkel L: Serum insulin-like factor 3 levels during puberty in healthy boys and boys with Klinefelter syndrome. J Clin Endocrinol Metab 2006;91:4705-4708.

60 Lague E, Tremblay JJ: Antagonistic effects of testosterone and the endocrine disruptor mono-(2-ethylhexyl) phthalate on INSL3 transcription in Leydig cells. Endocrinology 2008;149:4688-4694.

61 Tremblay JJ, Robert NM, Lague E: Nuclear receptors, testosterone, and posttranslational modifications in human INSL3 promoter activity in testicular Leydig cells. Ann NY Acad Sci 2009;1160:205-212.

62 Toshinai K, Mondal MS, Nakazato M, Date Y, Murakami N, Kojima M, Kangawa K, Matsukura S: Upregulation of Ghrelin expression in the stomach upon fasting, insulin-induced hypoglycemia, and leptin administration. Biochem Biophys Res Commun 2001;281:1220-1225.

63 Gaytan F, Barreiro ML, Caminos JE, Chopin LK, Herington AC, Morales C, Pinilla L, Paniagua R, Nistal M, Casanueva FF, Aguilar E, Dieguez C, Tena-Sempere M: Expression of ghrelin and its functional receptor, the type 1a growth hormone secretagogue receptor, in normal human testis and testicular tumors. J Clin Endocrinol Metab 2004;89: 400-409.

64 Tena-Sempere M, Barreiro ML, Gonzalez LC, Gaytan F, Zhang FP, Caminos JE, Pinilla L, Casanueva FF, Dieguez C, Aguilar E: Novel expression and functional role of ghrelin in rat testis. Endocrinology 2002; 143:717-725
65 Barreiro ML, Gaytan F, Caminos JE, Pinilla L, Casanueva FF, Aguilar E, Dieguez C, Tena-Sempere M: Cellular location and hormonal regulation of ghrelin expression in rat testis. Biol Reprod 2002;67:1768-1776.

-66 Ishikawa T, Fujioka H, Ishimura T, Takenaka A, Fujisawa M: Ghrelin expression in human testis and serum testosterone level. J Androl 2007;28:320-324.

67 Yan W, Linderborg J, Suominen J, Toppari J: Stage-specific regulation of stem cell factor gene expression in the rat seminiferous epithelium. Endocrinology 1999; 140:14991504

68 Zhang Y, Proenca R, Maffei M, Barone M, Leopold L, Friedman JM: Positional cloning of the mouse obese gene and its human homologue. Nature 1994;372:425-432.

69 Caprio M, Fabbrini E, Isidori AM, Aversa A, Fabbri A: Leptin in reproduction. Trends Endocrinol Metab 2001;12:65-72.

70 Caprio M, Isidori AM, Carta AR, Moretti C, Dufau ML, Fabbri A: Expression of functional leptin receptors in rodent Leydig cells. Endocrinology 1999;140:4939-4947.

-71 Tena-Sempere M, Manna PR, Zhang FP, Pinilla L, Gonzalez LC, Dieguez C, Huhtaniemi I, Aguilar E: Molecular mechanisms of leptin action in adult rat testis: potential targets for leptin-induced inhibition of steroidogenesis and pattern of leptin receptor messenger ribonucleic acid expression. J Endocrinol 2001;170:413-423.

72 Tchernof A, Despres JP, Belanger A, Dupont A, Prud'homme D, Moorjani S, Lupien PJ, Labrie F: Reduced testosterone and adrenal C19 steroid levels in obese men. Metabolism 1995;44:513-519.

73 Isidori AM, Caprio M, Strollo F, Moretti C, Frajese G, Isidori A, Fabbri A: Leptin and androgens in male obesity: evidence for leptin contribution to reduced androgen levels. J Clin Endocrinol Metab 1999;84:3673-3680.

74 Ishikawa T, Fujioka H, Ishimura T, Takenaka A, Fujisawa M: Expression of leptin and leptin receptor in the testis of fertile and infertile patients. Andrologia 2007;39:22-27.

75 Svechnikov K, Supornsilchai V, Strand ML, Wahlgren A, Seidlova-Wuttke D, Wuttke W, Soder O: Influence of long-term dietary administration of procymidone, a fungicide with anti-androgenic effects, or the phytoestrogen genistein to rats on the pituitary-gonadal axis and Leydig cell steroidogenesis. J Endocrinol 2005;187:117-124.

76 Svechnikov K, Svechnikova I, Soder O: Inhibitory effects of mono-ethylhexyl phthalate on steroidogenesis in immature and adult rat Leydig cells in vitro. Reprod Toxicol 2008;25:485-490. 